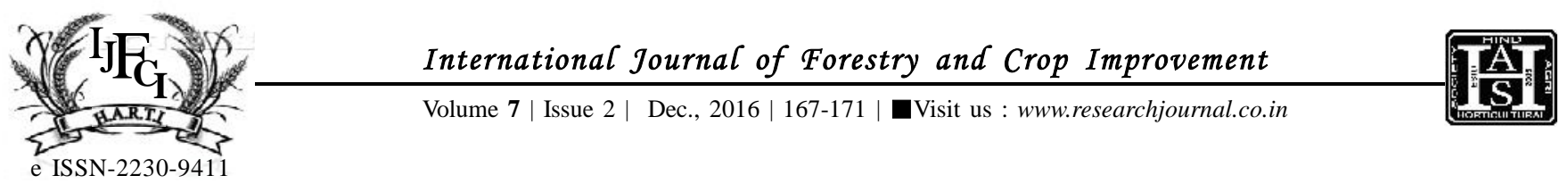

\title{
Studies on survival percentage of softwood grafting in mahua (Madhuca indica Gmel.J.F.) by using khirni (Manilkara hexandra Roxb.) as a root stock
}

\author{
C.V. Pohare, S.W. Choudhari, V.P. Mane, V.B. Shambharkar, U.A. Raut,H.K. Deshmukh and Y.B. \\ TAIDE
}

\begin{abstract}
Maduca indica Gmel.J.F. (Mahua) which belongs to family Sapotaceae is very important tree in Central and North India's forest and it plays significant role in livelihood of tribal economy of the country (Troup, 1921). The tree is slow growing and takes almost 08-10 years for flowering and fruiting. Mahua is ordinarily drought and frost hardy tree but it suffer under severe conditions. The viability of the seed for germination is very less, hence availability of viable seed of Mahua is always in question (Bhanja, 2000). Therefore, the the experiment on softwood grafting in Mahua was tried by using at using Khirni (Manilkara hexandra) as root stock at Department of Forestry, Dr.P.D.K.V.Akola. The experiment was carried out in Randomized Block Design with different month as a treatments (from July to January) and in three replication. The data recorded in respect of all the parameters such as days required for graft take, per cent of graft take, days require for sprouting, percentage of sprouting, number of leaf per graft and survival percentage etc. was statistically analysed. The interpretation of result obtained in the present investigation revealed that in different months of mahua grafting, October $\left(\mathrm{T}_{4}\right)$ was significantly superior in days require for grafttake, per cent of graft-take, days require for sprouting, percentage of sprouting, number of sprout per graft, number of leaves per graft and survival percentage at 60 DAG as compare to other months of treatment and vegetative growth of mahua grafts was also observed maximum when the grafting was done in the month of October.
\end{abstract}

KEY WORDS : Mahua (Madhuca indica), Softwood grafting, Survival percentage

How TO CITE THIS ARTICLE : Pohare, C.V., Choudhari, S.W., Mane, V.P., Shambharkar, V.B., Raut, U.A., Deshmukh, H.K. and Taide, Y.B. (2016). Studies on survival percentage of softwood grafting in mahua (Madhuca indica Gmel.J.F.) by using khirni (Manilkara hexandra Roxb.) as a root stock. Internat. J. Forestry \& Crop Improv., 7 (2) : 167-171, DOI: 10.15740/HAS/IJFCI/7.2/167-171.

Article Chronical : Received : 14.10.2016; Revised : 12.11.2016; Accepted : 25.11.2016

MEMBERS OF RESEARCH FORUM

Address of the Correspondence : S.W. CHOUDHARI, Department of Forestry, Dr.

Panjabrao Deshmukh Krishi Vidyapeeth, AKOLA (M.S.) INDIA

Email: swchoudhari@yahoo.com

Address of the Coopted Authors : C.V. POHARE, V.P. MANE, V.B. SHAMBHARKAR, H.K. DESHMUKH AND Y.B. TAIDE, Department of Forestry, Dr. Panjabrao Deshmukh Krishi Vidyapeeth, AKOLA (M.S.) INDIA

U.A. RAUT, Department of Horticulture, Dr. Panjabrao Deshmukh Krishi Vidyapeeth, AKOLA (M.S.) INDIA 